Charles Roesch PH D MD, Kenneth A. Haselby MD, Raymond R. Paradise PH D, Gopal Krishna MD, Stephen Dierdorf MD, Thomas M. Wolfe MD, Chalapathi C. Rao MD

\title{
Dopamine reverses cardiovascular depression of toxic doses of pentobarbitone in dogs
}

Pentobarbitone, $20 \mathrm{mg} \cdot \mathrm{kg}^{-1} \mathrm{~W}$ followed by infusion of $25 \mathrm{mg} \cdot \mathrm{kg}^{-1} \cdot \mathrm{hr}^{-1}$, produced a progressive decrease in mean arterial pressure in dogs from $113 \pm 17 \mathrm{mmHg}$ (SD) after one hour of infusion $1082 \pm 21 \mathrm{mmHg}$ afier 3.5 hours and to $49 \pm 22 \mathrm{mmHg}$ after 5.5 hours. EEG silence occurred at $3.6 \pm 0.6$ hours. In dogs similarly treated with pentobarbitone, a two hour infusion of dopamine $5 \mu \mathrm{g} \cdot \mathrm{kg}^{-1} \cdot \mathrm{min}^{-1}$ beginning at the time of EEG silence prevented the further decrease in pressure and restored pressure to $87 \pm 18 \mathrm{mmHg}$.

The mechanism for this effect of dopamine was an increase in cardiac output as systemic vascular resistance was unaffected by dopamine. The cardiac output increase was mainly the result of an increase in stroke volume as heart rate increased only slightly. Since reduced stroke volume was the main reason why pentobarbitone lowered blood pressure, the effect of dopamine on stroke volume and thus on blood pressure makes it an appropriate antagonist to the cardiovascular effects of roxic doses of pentobarbitone.

\section{Key words}

HYPNOTICS: pentobarbitone; HEART: cardiac output, dopamine; BRAIN: electroencephalography.

From the Departments of Anesthesia and Pharmacology, Indiana University Medical Center, Indianapolis, IN.

Address correspondence to: Kenneth Haselby, MD, Department of Anesthesia, Indian University School of Medicine, Indianapolis IN 46223.

Supported by grants from the Anesthesia Department and from the Anticonvulsent Drug Laboratory, Department of Surgery, Indiana University.
Barbiturates have been used in large doses to protect the brain from injury following hypoxia and to reduce intracranial pressure. ${ }^{1-4}$ This use may be complicated by cardiovascular depression. In a previous study ${ }^{5}$ comparing the cardiovascular effects of thiopentone and pentobarbitone in dogs, both barbiturates produced dose-related depressions of arterial pressure and cardiac output with little change in systemic vascular resistance. At drug concentrations less than those producing EEG silence there was no significant difference between the two agents except for a higher incidence of ventricular dysrhythmias in dogs given thiopentone. At drug concentrations greater than those producing EEG silence, pentobarbitone appeared to be the safer drug.

The present study evaluates whether dopamine, administered at a dosage rate producing minimal alpha adrenergic stimulation $\left(5 \mu \mathrm{g} \cdot \mathrm{kg}^{-1} \cdot \mathrm{min}^{-1}\right),{ }^{6}$ reverses the cardiovascular depression produced by toxic doses of pentobarbitone.

\section{Methods}

Seventeen mongrel dogs of both sexes weighing 8.5 to $21.5 \mathrm{~kg}$ were used. An induction dose of $20 \mathrm{mg}$. $\mathrm{kg}^{-1}$ pentobarbitone was followed immediately by an infusion of $25 \mathrm{mg} \cdot \mathrm{kg}^{-1} \cdot \mathrm{hr}^{-1}$ pentobarbitone into a foreleg vein for $5.5 \mathrm{hrs}$. The first hour of anaesthesia was used to place all recording devices. Ten blood samples $(1.5 \mathrm{ml}$ each) were drawn at $30 \mathrm{~min}$ intervals from the first hour until the end of the experiment for subsequent plasma pentobarbitone assay. $^{5}$

Tracheal lubes were placed and ventilation controlled with a Bennett Model BA-4 ventilator using 
40 per cent $\mathrm{O}_{2}, 60$ per cent $\mathrm{N}_{2}$. End tidal $\mathrm{CO}_{2}$ was monitored with a Beckman LB-1 analyzer and ventilation adjusted to a $\mathrm{PaCO}_{2}$ of $30-40 \mathrm{mmHg}$. Arterial $\mathrm{pH}$ was maintained between 7.35 and 7.45 . Base deficit was adjusted with sodium bicarbonate if greater than 3-4 meq $\cdot \mathrm{l}^{-1}$. A thermistor probe was inserted in the pharynx and body temperature was maintained at $36^{\circ} \mathrm{C}$ to $40^{\circ} \mathrm{C}$ by the use of a heat lamp and/or plastic covers.

A femoral artery and jugular vein were cannulated to monitor arterial pressure and central venous pressure respectively. A thermistor-tipped pulmonary arterial catheter was inserted via the femoral vein. The position of the catheter was verified by pressure wave form. Duplicate thermodilution cardiac output measurements were made using $3 \mathrm{ml}$ iced normosal " $\mathrm{m}$ " injections. All three pressure transducers (Statham P23Db, ten volt) were connected to a Grass Model 5 polygraph. An eightchannel Grass Model 6 EEG was used to monitor cortical activity using two frontal (F3 and F4), two posterior (P3 \& P4), and one central (Cz) electrodes. Leads monitored were (1) F3-C2; (2) $\mathrm{P} 3-\mathrm{Cz}$; (3) F4-Cz; (4) P4-Cz; (5) F3-P3; (6) F4-P4; and (7) F3-P3. Channel 8 was used for the electrocardiogram (ECG) signal measured across the chest wall.

Every 10-15 min EEG recordings were made. EEG silence occurred after 3.6 \pm 0.6 (Mean $\pm S D$ ) hrs of pentobarbitone infusion at a plasma concentration of $70 \pm 15 \mathrm{mg} \cdot \mathrm{l}^{-1}$

Cardiovascular data measured or calculated at $30 \mathrm{~min}$ intervals from $1-5.5 \mathrm{hrs}$ included heart rate, stroke volume $/ \mathrm{kg}$, cardiac output $/ \mathrm{kg}$, systemic vascular resistance (mean arterial pressure minus central venous pressure divided by cardiac output $/ \mathrm{kg}$ ), mean arterial pressure and central venous pressure.

Dopamine $\left(5 \mu \mathrm{g} \cdot \mathrm{kg}^{-1} \cdot \mathrm{min}^{-1}\right)$ was infused in five of the 17 dogs after EEG silence was reached (at approximately $3.5 \mathrm{hrs}$ ) and the infusion continued for two additional hrs with cardiovascular data and plasma pentobarbitone concentrations determined at $30 \mathrm{~min}$ intervals.

The remaining 12 dogs served as controls. Cardiovascular data and pentobarbitone concentrations from all 17 dogs were pooled and averaged for the first 3.5 hours (first six data points). The four data points for the control and dopamine experiments obtained after 3.5 hours were normalized to the pre-dopamine values (6th data point in Figs. 1 and 2). Statistical analyses of the dopamine effects were done using analysis of variance followed by the student-Newman-Keuls' test. ${ }^{7}$ A P value of 0.05 or less was considered statistically significant.

\section{Results}

Following an induction dose of $20 \mathrm{mg} \cdot \mathrm{kg}^{-1}$ pentobarbitone and an infusion of $25 \mathrm{mg} \cdot \mathrm{kg}^{-1} \cdot \mathrm{hr}^{-1}$ for one hour in 12 control dogs the plasma concentration averaged $42.7 \mathrm{mg} \cdot \mathrm{l}^{-1}$. Subsequent infusion at a rate of $25 \mathrm{mg} \cdot \mathrm{kg}^{-1} \cdot \mathrm{hr}^{-1}$ for an additional $4.5 \mathrm{hrs}$ resulted in a linear increase in plasma concentration. The increase averaged $11.8 \pm 3.5$ $\mathrm{mg} \cdot \mathrm{kg}^{-1} \cdot \mathrm{hr}^{-1}$ (mean $\pm \mathrm{SD}$ ) as determined from samples taken every $30 \mathrm{~min}$. The rate of change of plasma pentobarbitone concentration was $11.8 \pm$ $3.3 \mathrm{mg}^{\prime} \mathrm{l}^{-1} \cdot \mathrm{hr}^{-1}$ in five dogs similarly treated with pentobarbitone but in which dopamine 5 $\mu \mathrm{g} \cdot \mathrm{kg}^{-1} \cdot \mathrm{hr}^{-1}$ was additionally infused at the $3.5 \mathrm{hr}$ period until the $5.5 \mathrm{hr}$ period.

Infusion of $25 \mathrm{mg} \cdot \mathrm{kg}^{-1} \cdot \mathrm{hr}^{-1}$ pentobarbitonc after an induction dose of $20 \mathrm{mg} \cdot \mathrm{kg}^{-1}$ resulted in concentration-dependent reductions in heart rate, stroke volume $\cdot \mathrm{kg}^{-1}$, cardiac output $\cdot \mathrm{kg}^{-1}$ (Fig. 1) and mean arterial pressure (Fig. 2). Dopamine infusion $\left(5 \mu \mathrm{g} \cdot \mathrm{kg}^{-1} \cdot \mathrm{min}^{-1}\right)$, started at approximately 3.5 hours after pentobarbitone induction, reversed the downward trend in these cardiovascular data (Figs. 1 and 2).

Systemic vascular resistance did not change with increasing pentobarbitone concentrations and was not significantly affected by dopamine (Fig. 2). The course of the increase in central venous pressure seen during pentobarbitone infusion was not altered by dopamine (Fig. 2).

\section{Discussion}

The pharmacological actions of dopamine on the cardiovascular system are dose-dependent. At low doses two actions predominate. A release of norepinephrine from storage depots in ventricular tissue $^{10.11}$ results in an increase in contractility ${ }^{10,11}$ and stroke volume. ${ }^{12}$ This effect is similar to that seen with tyramine and, as with tyramine, is inhibited by reserpine and desmethylimipramine. ${ }^{10,11}$ Also seen at low doses is a reduction of resistance in the renal and mesenteric circulations attributed to specific dopaminergic receptor activation. ${ }^{13,14}$ At higher doses, actions on beta ${ }_{1}$ and alpha receptors $_{1}$ become prominent resulting in an increase in heart rate, ${ }^{11}$ a further increase in contractility 11 and an 


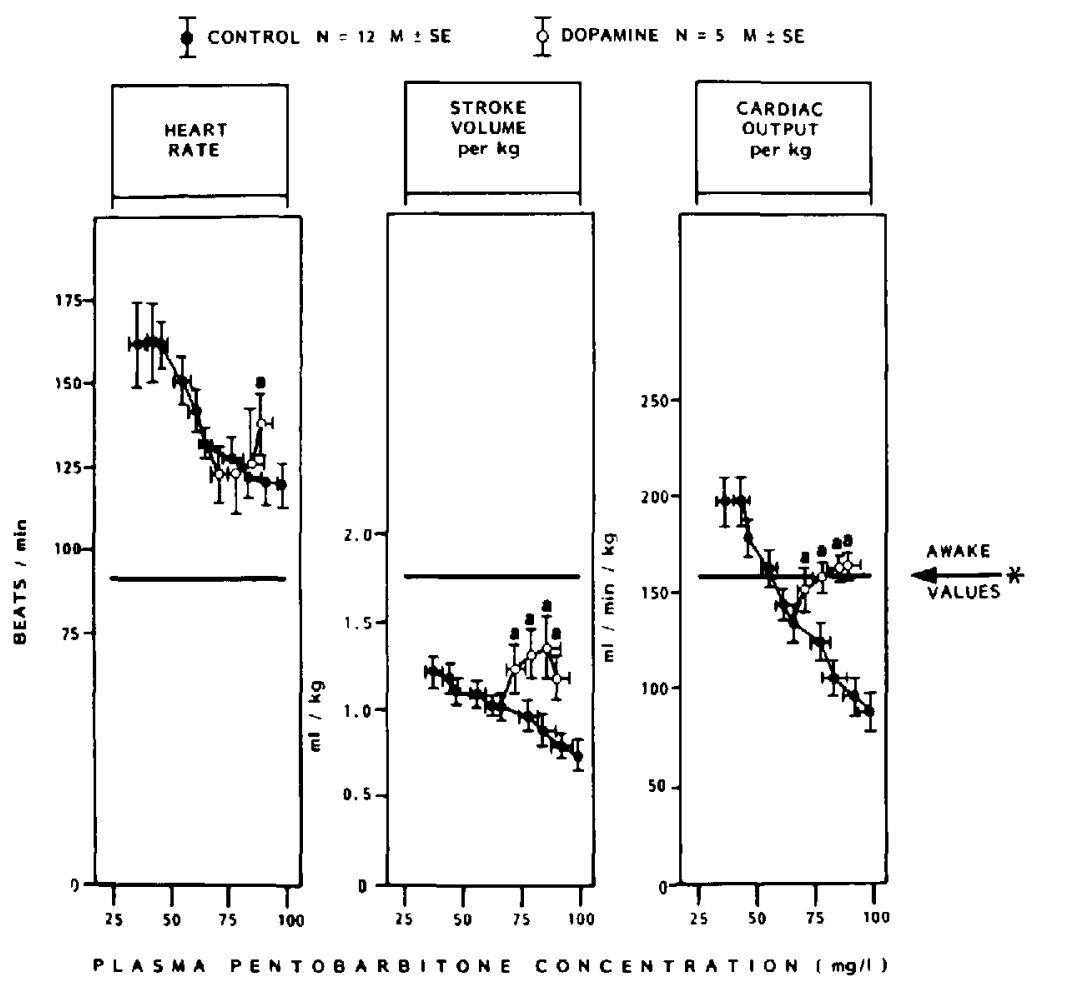

FIGURE l Effects of dopamine on heart rate, stroke volume per $\mathrm{kg}$ und cardiac output per $\mathrm{kg}$ in dogs during deep pentobarbitone anaesthesia. Seventeen dogs were given $20 \mu \mathrm{g} \cdot \mathrm{kg}^{-1}$ pentobarbitone IV for induction then $25 \mathrm{mg} \cdot \mathrm{kg}^{-1} \cdot \mathrm{hr}^{-1}$ for 5.5 hours. In five of the 17 dogs dopamine infusion $\left(5 \mu \mathrm{g} \cdot \mathrm{kg}^{-1} \cdot \mathrm{min}^{-1}\right)$ was started approximately 3.5 hours after induction of anacsthesia and continued for two hours. *Awake dog values from Merin et al. ${ }^{8} \mathrm{a}=$ Dopamine value is significantly different $(\mathrm{p}<0.05)$ from last four control values.

increase in resistance in blood vessels supplied with alpha $_{1}$ receptors. ${ }^{15}$

Effects seen in this study with dopamine infused at a rate of $5 \mu \mathrm{g} \cdot \mathrm{kg}^{-1} \cdot \mathrm{min}^{-1}$, namely an increase in stroke volume with little change in heart rate, are thus characteristic of those effects seen with low doses of dopamine and serve to explain the increase in mean arterial pressure. Thus pentobarbitone, in toxic doses, does not prevent the cardiac actions of dopamine involved in restoring arterial pressure. Phenobarbitone induced hypotension is also reversed by dopamine in dogs ${ }^{16,17}$ and in a child. ${ }^{17}$

We were surprised at the continued increase in stroke volume over a period of $1 \frac{1}{2}$ hrs of infusion in view of the report by Jarnberg et al. in humans ${ }^{18}$ who stated that plasma levels of dopamine, when administered at a rate of 2 and $5 \mu \mathrm{g} \cdot \mathrm{kg}^{-1} \cdot \mathrm{min}^{-1}$, reach a steady state in $5 \mathrm{~min}$. Analysis of Figure 1 of their paper, however, showed a plasma level of approximately $375 \mathrm{nM}$ in $5 \mathrm{~min}$ with a rise of approximately $300 \mathrm{nM} \cdot \mathrm{hr}^{-1}$ occurring over the next $30 \mathrm{~min}$. A steady increase in stroke volume over a $30 \mathrm{~min}$ period of dopamine infusion $\left(5 \mu \mathrm{g} \cdot \mathrm{kg}^{-1}\right.$. $\mathrm{min}^{-1}$ ) is suggested by the data of Harrison et al. ${ }^{19}$ and Black and Rolett ${ }^{12}$ in dogs anaesthetized with chloralose and urethane. They reported eight per cent $^{19}$ and 31 per cent ${ }^{12}$ increases in stroke volume after five and $30 \mathrm{~min}$ respectively. From their data and ours it is evident that anaesthetized dogs do not reach a steady-state with respect to effects on stroke 


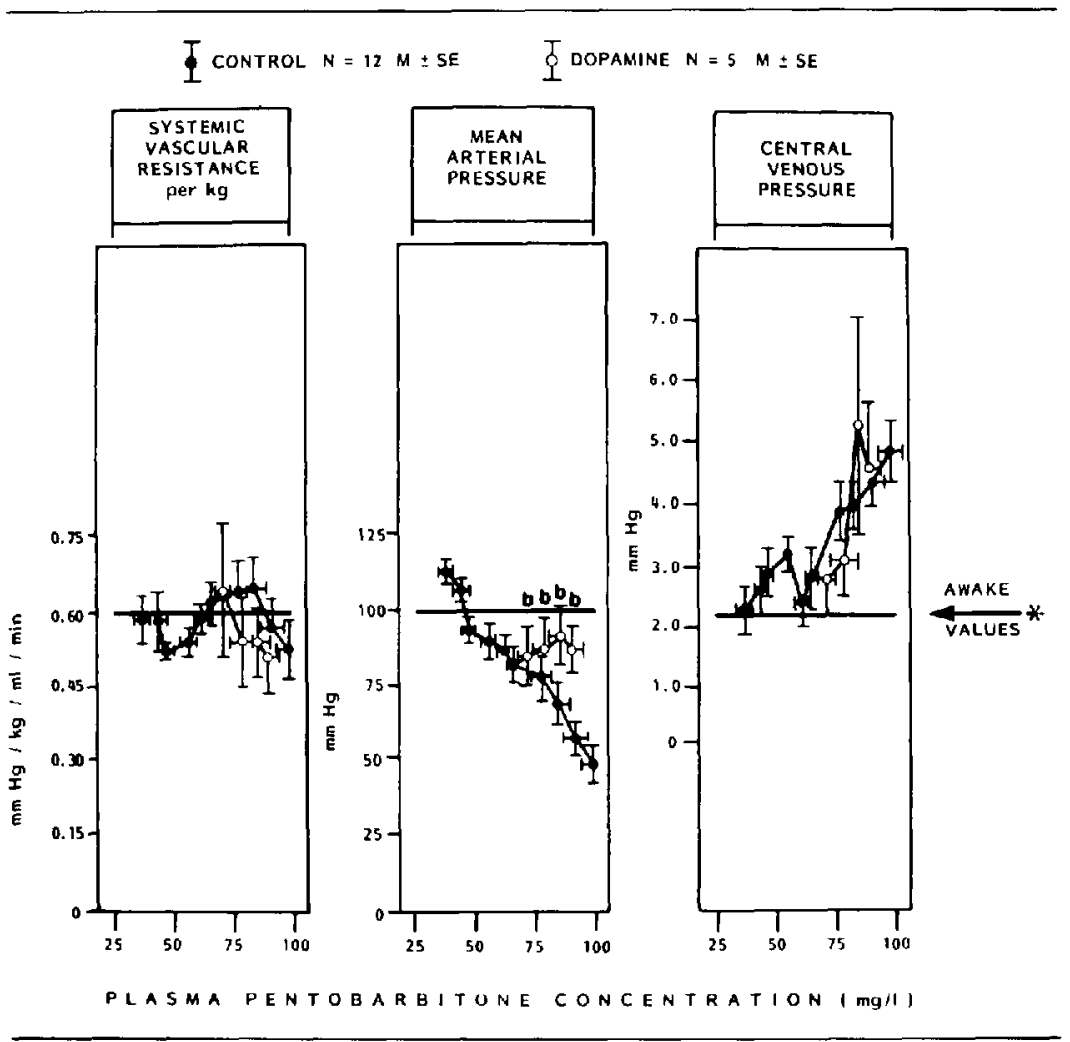

FIGURE 2 Effccts of dopamine on systemic vascular resistance per $\mathrm{kg}$, mean arterial pressure and centra! venous pressure. ${ }^{*}$ A wake dog values from Merin et al. ${ }^{8}$ except $\mathrm{CVP}$ which was from Cox. ${ }^{9} \mathrm{~b}=$ Dopamine value is significantly different $(p<0.05)$ from last two control values.

volume in $5 \mathrm{~min}$ at an infusion rate of $5 \mu \mathrm{g} \cdot \mathrm{kg}^{-1}$. $\min ^{-1}$.

In our study dopamine was administered at toxic plasma concentrations of pentobarbitone producing electroencephalographic silence $\left(70 \pm 15 \mathrm{mg} \cdot \mathrm{l}^{-1}\right)$. These concentrations are higher than those achieved by Caseby $\left(25-40 \mathrm{mg} \cdot \mathrm{l}^{-1}\right)$ during successful treatment of a patient with postpartum stroke. ${ }^{20}$

Since dopamine reversed the pentobarbitoneinduced decrease in mean arterial pressure and did so primarily by an effect on stroke volume it is an appropriate antagonist to the cardiovascular effects of toxic doses of pentobarbitone.

\section{Acknowledgements}

We thank Professor Elizabeth Solow, Neurological Surgery Research Laboratory, for assistance with the barbiturate assays and Dr. S.S. Moorthy,
Department of Anesthesia, for his help in setting up the electroencephalograph and interpreting the patterns.

\section{References}

1 Shapiro $H M$. Intracranial hypertension: therapeutic and anesthetic considerations. Anesthesiology 1975; 43: 445-71.

2 Marsh ML, Marshall LF, Shapiro HM. Neurosurgical intensive care. Anesthesiology 1977; 47: 149-63.

3 Smith AL. Barbiturate protection in cerebral hypoxia. Anesthesiology 1977; 47: 285-93.

4 Marshall LF, Shapiro HM, Rauscher A, Kaufman $N M$. Pentobarbital therapy for intracranial hypertension in metabolic coma. Reye's syndrome. Crit Care Med 1978; 6: 1-S.

5 Roesch C, Haselby KA, Paradise RR et al. Com- 
parison of cardiovascular effects of thiopental and pentobarbital at equivalent levels of CNS depression. Anesth Analg 1983; 62: 749-53.

6 Goldberg LL. Cardiovascular and renal actions of dopamine: potential clinical applications. Pharmacol Rev 1972; 24: 1-29.

7 Steel RGD, Torrie JH. Principles and procedures of statistics. New York, McGraw-Hill, 1960, pp 112-4.

8 Merin RG, Kumazawa T, Luka NL. Enflurane depresses myocardial function, perfusion, and metabolism in the dog. Anesthesiology 1976; 45: 501-7.

$9 \mathrm{Cox} R H$. Influence of pentobarbital anesthesia on cardiovascular function in trained dogs. Am J Physiol 1972; 223: 651-9.

10 Tuttle RR. Changes in cardiovascular effects of dopamine caused by desmethylimipramine and reserpine. Pharmacologist 1970; 12: 213.

11 Tuttle RR, Mills J. Development of a new catecholamine to selectively increase cardiac contractility. Circ Res 1975; 36: 186-96.

12 Black WL, Rolett EL. Dopamine-induced alterations in left ventricular performance. Circ Res 1966; 19: 71-9.

13 Eble JN. A proposed mechanism for the depressor effect of dopamine in the anesthetized dog. J Pharmacol Exper Therap 1964; 145: 64-70.

14 Goldberg $L I$. The dopamine vascular receptor. Biochem Pharmacol 1975; 24: 651-3.

15 Higgins $C B$, Millard $R W$, Braunwald $E$ et al. Effects and mechanisms of action of dopamine on regional hemodynamics in the conscious dog. Am J Physiol 1973; 225: 432-7.

16 Gifford RRM, Brock HT, Dayton PG et al. Increased clearances of phenobarbital and salicylate produced by dopamine in the dog. Am J Med Sci 1969; 258: 351-8.

17 Gifford RRM, Garrettson LK, Dayton PG et al. Use of dopamine in phenobarbital intoxication. Clin Res 1968; 16: 27.

18 Jarnberg P-O, Bengtsson L, Ekstrand J et al. Dopamine infusion in man. Plasma catecholamine levels and pharmacokinetics. Acta Anaesthesiol Scand 1981;25: 328-31.

19 Harrison DC, Pirages S, Robison SC et al. The pulmonary and systemic circulatory response to dopamine infusion. Br J Pharmacol 1969; 37: 618-26.

20 Caseby NG. Postpartum stroke successfully treated with high dose pentobarbitone therapy: a case report. Can Anaesth Soc J 1983; 30: 77-83.

\section{Résumé}

Le pentobarbitone administré à hautes doses $(20 \mathrm{mg}$. $\mathrm{kg}^{-1}$, dose d' attaque suivie d' une infusion de $25 \mathrm{mg} \cdot \mathrm{kg}^{-1}$ par heure) à des chiens a produit une diminution progressive de la pression artérielle moyenne. En effet, chez les animaux ainsi traités la pression artêrielle moyenne est passée de $113 \pm 17 \mathrm{mmHg}$ après une heure d'infusion à $82 \pm 21 \mathrm{mmHg}$ après trois heures et demie el à $49 \pm 22 \mathrm{mmHg}$ uprès cinq heures et demie de ce traitement. Le silence encéphalographique s'est établi après $3.6 \pm 0.6$ hre. Chez d'autres chiens traités de la même façon au pentobarbitone, une infusion de dopamine $5 \mu \mathrm{g} \cdot \mathrm{kg}^{-1}$ par minute pendant deux heures, commencée au début du silence electroencéphalographique, a stoppé la descente de la pression artérielle et l'a rétablie à $87 \mathrm{mmHg} \pm 18$.

C'est par l'augmentation du débit cardiaque que cet effet s'est manifesté car les résistances vasculaires systémiques n'ont pas été modifées par la dopamine. Cette augmentation de débit cardiaque était surtout le résultat d' une augmentation du volume d'éjection car la fréquence cardiaque s'est à peine modifiée. Comme c'est par réduction du volume d' ejection que le pentobarbitone avait diminué la pression artérielle, la dopamine, en rétablissant le volume d'ejection, apparait donc d'un choix judicieux pour contrer les effets cardiovasculaires indésirables de doses toxiques de pentobarbitone. 